Автопобажальні конструкції структурної схеми $\mathrm{N}_{1} \mathrm{Vf}_{\text {deslsg/pl(cop) }}$ Part $_{1 / 5}$ виражають бажану якісну характеристику семантичного суб'єкта суб'єкта мовлення: Нехай я буду з Тобою розп'ятий, а не спасаю своє життя для себе самого (М. Ярема).

Автопобажальні конструкції структурної схеми $\mathrm{N}_{1} \mathrm{Vf}_{\text {des1sg(cop) }} \mathrm{N}_{2,3 \ldots}$ виражають бажану непостійну ознаку (рід діяльності, стан, локалізацію тощо) семантичного суб'єкта - суб'єкта мовлення: Не держіть мене як дочку, нехай я буду вам замість наньмички: усяку роботу, що скажете, буду робити і не охну. (Г. Квітка-Основ'яненко).

\title{
Література:
}

1. Городенська К. Г. Семантична структура імператива. Актуальні проблеми граматики : зб. наук. пр. Кіровоград: Кіровоградський педагогічний інститут ім. В. К. Винниченка, 1996. Вип. 1. С. 63-68.

2. Граматика сучасної української мови. Морфологія / Вихованець I. Р., Городенська К. Г., Загнітко А. П., Соколова О. С. К.: Видавничий дім Дмитра Бураго, 2017. 752 с.

DOI https://doi.org/10.30525/978-9934-26-110-7-9

\section{РЕПРЕЗЕНТАЦІЯ АНТРОПОНІМІВ У ПАМ'ЯТКАХ ДАВНЬОЇ ЛЕКСИКОГРАФІЇ}

\section{Чорноус О. В.}

кандидат філологічних наук, доцент, завідувач кафедри загальної підготовки та сочіальної роботи Кропивницький інститут державного та муніџипального управління м. Кропивницький, Україна

На сьогодні питання про те, коли саме 3'явилися перші праці, об'єктом студіювання яких були антропоніми, не отримало однозначної відповіді. Утім відомо, що вже в античності філософи сперечалися щодо походження пропріативів загалом та власних назв людей зокрема. Деякі їхні висновки були підтверджені кількома століттями пізніше в результаті вже наукового вивчення онімів: наприклад, Аристотелем було спостережено здатність власних назв позначати одиничні, унікальні об'єкти, яке він проілюстрував твердженням «Сонце - дещо одиничне, подібно до Клеона чи Сократа» [2, с. 219]. 
В. Лучик, характеризуючи стан та перспективи розвитку слов'янської ономастики, підкреслював іiі давність у розмовному мовленні, фольклорі, писемних джерелах, одночасно вказуючи на те, що спроби пояснити окремі власні назви, зокрема антропоніми, здійснювалися задовго до того, коли постала ономастична наука [7, с. 210]. Переконливим прикладом можуть послугувати тлумачні словники XIII ст., у яких пояснювалося значення іншомовних слів, зокрема єврейських, грецьких, сербських, болгарських, що траплялися в церковних книгах [3, с. 181]. До реєстру укладачами часто добиралися як апелятиви, так і пропріативи, що потребували відповідних коментарів.

Однією 3 таких східнослов'янських праць XIII ст. $€$ рукописний тлумачний словничок «Рђчь Жидовьскаго язика, преложена на роускоую, нерозумно на розоумъ, и в Сванглихъ, и въ Ап(с)лхъ, и въ Псалтыри, и в Пармиһ и въ прочихъ книгах», уміщений у кормчій книзі 1282 р., написаній для новгородського єпископа Климента [1, с. 209]. Об'єктом для тлумачень послугували уживані в біблійних текстах та потрактовані автором як неперекладені й незрозумілі 174 лексеми, 3поміж яких чільне місце посіли чоловічі й жіночі наймення: Петръ,

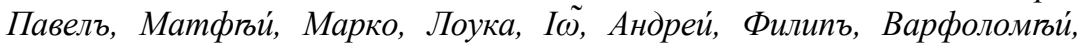
Фома, Дгвора, Сара, Ревека тощо [11, с. 195-196]. До кожного 3 особових імен у словничку був запропонований відповідник давньоруською мовою з церковнослов'янськими лексичними рисами: Андреи́ «сила», Фома - «бездьна», Симонъ - «ловець», Ревека - «радость», Дгвора - «пчела» тощо. Виявлений список $є$ значущим для вітчизняної ономастики, адже на думку Я. Щапова, саме ним послуговувалися на територіях теперішньої України [12, с. 14-17].

Інший рукопис «О именЂхъ и глемыхъ жидовьскымь 1азыкъмь» вважається перекладом збірника грецьких словників. Його найдавніший список - коротка редакція в Ізборнику XIII ст. - розтлумачує значення багатьох давньоєврейських за походженням імен: авраӓмь - «оць вышнлго- илли оць странамъ»; исакъ - «смЂхъ иंли радость»; соумеонъ «послоушаиі»; июода - «иісповьданьє்», девора - «·бчела» тощо [10]. Повна редакція цього словника міститься в списку XIV ст. та репрезентує дещо ширший іменник, який зокрема поповнили наймення гвга («жизнь. пара илли сьтва»), самоиіъ. («слуга биґа), самуиль («просвظщениґ $\overline{\mathbf{w}}$ ба»), ижакимъ. («лежаи.») та інші антропоніми [9].

У наступні століття лексикографічне опрацювання антропонімного матеріалу пов'язують 3 іменем Максима Грека. Три списки другої редакції його праці «Толкованія ймень по алфавиту» уналежнюють до південно-західних, що фактично означає їхнє українське або білоруське 
походження $[4$, с. $118 ; 8$, с. 352-353]. Український список кінця XVI - початку XVII ст. зі збірника ДА/П. 521 ЦНБ АН України, що зберігає найбільше риси звукової системи української мови (передусім іiі північних говорів), пропонує інтерпретацію багатьох уживаних донині

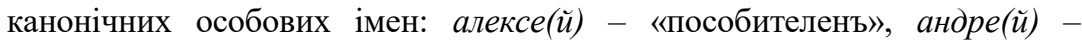

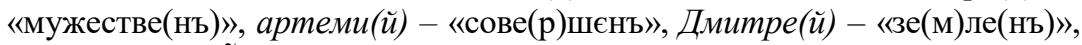
евгени(й) - «блггороденъ», н[и]кита - «победите(л)», Өекла - «бого(м) звана», марїя - «Г(с)жа» тощо [8, с. 11-19]. Доречно зауважити, що на відміну від попереднього словника він охоплює не лише традиційні єврейські оніми, а й латинські та грецькі запозичення.

Наприкінці XVI ст. антропоніми вперше постають матеріалом не тлумачного, а перекладного двомовного словника «Лексисъ съ толкованіемъ словенскихъ мовъ просто», доданого до Острозької біблії (1581 р.). До особових імен церковнослов'янською мовою укладач дібрав відповідники українською або, кажучи мовою оригіналу, «просто», зрозумілою для нижчих верств населення: анна - «благодатель», алексе(й) - «пособитель», архипъ - «началникъ конемъ, конюшій» та інші [6]. Цікавим видається обмежене коло чоловічих та жіночих наймень порівняно з попередніми лексикографічними працями.

Традиції укладання реєстрів та інтерпретації антропонімів продовжив видатний діяч української культури Памво Беринда у своїй роботі «Лексіконъ славенорюсскій и именъ Тлъкованїє», що за твердженням В. Німчука, є однією з кращих праць східнослов'янської лексикографії

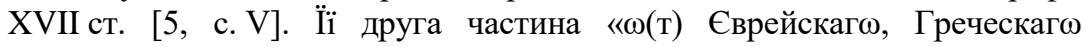
же и Латінскаг, и и $\omega($ т) иных Языкювъ начынающаАсА Имена свойственна А...» являє собою словник іншомовних слів, загальних і власних назв, що траплялися в тогочасній літературі, які Памво Беринда переклав або розтлумачував українською літературною мовою XVII ст. 3-поміж них фіксуємо чимало особових імен: Аверкій, Атапій, Атріпіна, Адріанъ, Бонифацій, Василій, Зинаїда, Людмила, Пелагіа, Ревекка тощо. В. Німчук звертає увагу на те, що для коректного тлумачення власних назв автор звертався до ономастикона Максима Грека, Мануїла Ритора, а також окремого тому 3 тлумаченням власних назв багатомовного видання Біблії, відомої як Антверпенська Поліглота (побачила світ у 1568-1573 рр.): Іса́акъ - «радость смЂхъ», Клаvдіa - «хромаа», Маріна - «морскаа» тощо [5].

За результатами спостереження можна констатувати, що першопочатково антропоніми постали об'єктом уваги укладачів лексикографічних праць, які здебільшого ставили собі за мету розтлумачити їх значення. 


\section{Література:}

1. Азбуковник. Энииклопедический словарь / Ф. А. Брокгауз, И. А. Ефрон. Санкт-Петербург, 1890. Т. 1. С. 209-211.

2. Аристотель. Сочинения в четырех томах / ред. В. Ф. Асмус. Москва : «Мысль», 1976. Т. 1. 550 с.

3. Иванов А. И. Максим Грек как ученый на фоне современной ему русской образованности. Богословские трудыл. 1976. № 16. С. 142-187.

4. Ковтун Л. С. Лексикография в Московской Руси XVI - начала XVII в. Москва, Ленинград : Наука, 1975. 351 с.

5. Лексикон словенороський Памви Беринди : пам'ятки української мови XVII ст. / Академія наук Української РСР, Інститут мовознавства ім. О. О. Потебні; відпов. ред. К. К. Цілуйко, передм. В. В. Німчук. Киев: друк. видавництва АН РСР, 1961. - 272 с.

6. Лексисъ съ толкованіемъ словенскіхъ мовъ просто. Лексис Лаврентія Зизанія. Синоніма славеноросская / підг. текстів пам'яток і вступ. ст. В. В. Німчука. Київ : Наукова думка, 1964. 259 с.

7. Лучик В. Слов'янська ономастика: стан і перспективи розвитку. НЗ ТНПУ. Сер: Мовознавство. 2017. Вип. 1 (27). С. 210-212.

8. Максим Грек. Тлумачення імен за алфавітом. Украӥнські гуманісти епохи Відродження: антологія : у 2 ч. Київ : Наукова думка, Основи, 1995. Ч. 2. 429 с.

9. О именех глаголемых жидовским язиком. URL: http://oldlexicons.ru/ o_imeneh (дата звернення: 01.05.2021).

10. О именьхъ и глемыхъ жидовьскымь языкъмь (PC). URL: http://oldlexicons.ru/o_imeneh_glemyh_zhidovskim_jazykom_pc (дата звернення: 01.05.2021).

11. Ръчь Жидовьскаго азыка преложена на Роускоую, неразоумно на разоумъ, и въ ІСванг̃лихъ, и въ Апслхъ. и въ Псалтыри, и в Пармиђ и въ прочихъ книгахъ. Лексис Лаврентія Зизанія. Синоніма славеноросская / підг. текстів пам'яток і вступ. ст. В. В. Німчука. Київ : Наукова думка, 1964. $259 \mathrm{c}$.

12. Щапов Я. Древнерусские княжеские уставы XI - XV вв. Москва : Наука, 1976. 240 с. 